\title{
Role of USP 18 in Immune Response to Chronic Viral Infection
}

\section{Moyen Uddin PKM*}

Department of Biochemistry, Primeasia University, Bangladesh

Type I IFNs is vital for host defense against viral and bacterial infections. In addition, type I IFNs are also acknowledged to be involved in many immunoregulatory processes, such as NK cell activation [1] and proliferation/survival of CD8 $+\mathrm{T}$ cells $[2,3]$. Beside their well-known role in innate immunity, type I IFNs are constitutively expressed at a low level to ensure the maintenance of cellular homeostasis and may also play a role in shaping the adaptive immunity [4-6]. This constitutive IFN expression may, however, have detrimental effects if not tightly controlled. Usp18 is an IFN-inducible cysteine protease of the ubiquitin-specific protease family [7] and acts as an ISG15 deconjugating protease in the ISGylation system [8]. Furthermore, Usp18 functions in the type I IFN pathway by down regulating the JAK/STAT pathway independently of its isopeptidase activity through an interaction between Usp18 and the IFNAR2 subunit of the type I IFN receptor complex, whereas neither IFNAR1 nor IFNGR1 (type II IFN) receptor subunits were able to interact with Usp18 [9]. Usp18-deficient cells have enhanced IFN-a/b signaling and more ISG15 modified proteins [10]. As confirmed by gene expression microarray, the expression of IFN-inducible genes is increased and prolonged in the absence of Usp18 [8]. Accordingly, a deficiency in Usp18 increases the sensitivity of cells to IFN-I [9]. Consistently, Usp18-deficient mice exhibit limited viral replication after infection. How Usp18 expression influences the immune response, however, is still not completely understood. The amount of antigen presented is a crucial determinant of the adaptive immune response. In vitro studies found that only 10 peptide-MHC (pMHC) complexes can form an immunological synapse between DCs and T cells [10]. However, lowaffinity T-cell receptors (TCRs) require a larger dose of antigen than high-affinity TCRs [11]. Henrickson et al. found that DCs require at least $2 \times 10^{4} \mathrm{pMHC}$ complexes to induce T-cell proliferation in lymph nodes in vivo. Additionally, the duration of the initial priming phase is inversely correlated with the amount of antigen presented [12].These findings suggest that a larger dose of antigen improves T-cell immunity. Consistently, low-dose application of inactivated virus results in limited induction of neutralizing antibodies, whereas replicating virus leads to a strong antibody response $[13,14]$. Accordingly, a specific compartment that promotes viral replication and increases the presented dose of antigen might improve the adaptive immune response.

\section{References}

1. Biron CA, Nguyen KB, Pien GC, Cousens LP, Salazar-Mather TP (1999) Natural killer cells in antiviral defense: function and regulation by innate cytokines. Annu Rev Immunol 17: 189-220.

2. Marrack P, Kappler J, Mitchell T (1999) Type I interferons keep activated T cells alive. J Exp Med 189: 521-530.

3. Tough DF, Borrow P, Sprent J (1996) Induction of bystander T cell proliferation by viruses and type I interferon in vivo. Science 272: 1947-1950.

4. Taniguchi T, Ogasawara K, Takaoka A, Tanaka N (2001) IRF family of transcription factors as regulators of host defense. Annu Rev Immunol 19: 623655 .

5. Honda K, Takaoka A, Taniguchi T (2006) Type I interferon [corrected] gene induction by the interferon regulatory factor family of transcription factors. Immunity 25: 349-360.

6. Takaoka A, Mitani Y, Suemori H, Sato M, Yokochi T, Noguchi S, et al. (2000) Cross talk between interferon-gamma and -alpha/beta signaling components in caveolar membrane domains. Science 288: 2357-2360.
7. Liu LQ, Ilaria R Jr, Kingsley PD, Iwama A, van Etten RA, et al. (1999) A novel ubiquitin-specific protease, UBP43, cloned from leukemia fusion protein AML1 ETO-expressing mice, functions in hematopoietic cell differentiation. Mol Cell Biol 19: 3029-3038.

8. Malakhov MP, Kim KI, Malakhova OA, Jacobs BS, Borden EC, et al. (2003) High-throughput immunoblotting. Ubiquitiin-like protein ISG15 modifies key regulators of signal transduction. J Biol Chem 278: 16608-16613.

9. Irvine DJ, Purbhoo MA, Krogsgaard M, Davis MM (2002) Direct observation of ligand recognition by T cells. Nature 419: 845-849.

10. Holler PD, Kranz DM (2003) Quantitative analysis of the contribution of TCR/ pepMHC affinity and CD8 to T cell activation. Immunity 18: 255-264.

11. Henrickson SE, Mempel TR, Mazo IB, Liu B, Artyomov MN, et al. (2008) T cell sensing of antigen dose governs interactive behavior with dendritic cells and sets a threshold for T cell activation. Nat Immunol 9: 282-291.

12. Bachmann MF, Kündig TM, Kalberer CP, Hengartner H, Zinkernagel RM (1993) Formalin inactivation of vesicular stomatitis virus impairs T-cell- but not T-helpindependent B-cell responses. J Virol 67: 3917-3922.

13. Mandl JN, Barry AP, Vanderford TH, Kozyr N, Chavan R, et al. (2008) Divergent TLR7 and TLR9 signaling and type I interferon production distinguish pathogenic and nonpathogenic AIDS virus infections. Nat Med 14: 1077-1087.

14. Bosinger SE, Sodora DL, Silvestri G (2011) Generalized immune activation and innate immune responses in simian immunodeficiency virus infection. Curr Opin HIV AIDS 6: 411-418.
*Corresponding author: Moyen Uddin PKM, Department of Biochemistry, Primeasia University, Bangladesh, Tel: 88-01816487617; E-mail: moyen. uddinpk@primeasia.edu.bd

Received April 13, 2015; Accepted May 26, 2015; Published May 28, 2015

Citation: Uddin PKMM (2015) Role of USP 18 in Immune Response to Chronic Viral Infection. J Med Microb Diagn 4: 189. doi:10.4172/21610703.1000189

Copyright: @ 2015 Uddin PKMM. This is an open-access article distributed under the terms of the Creative Commons Attribution License, which permits unrestricted use, distribution, and reproduction in any medium, provided the original author and source are credited. 